\title{
Effect of the soil treated with biochar on the rye-grass in laboratory experiment
}

\author{
Miklós GULYÁS,,$^{1 *}$ Márta FUCHS, ${ }^{1}$ István KOCSIS, ${ }^{2}$ \\ György FÜLEKY ${ }^{1}$ \\ ${ }^{1}$ Department of Soil Science and Agricultural Chemistry, Szent István University, Gödöllö, \\ Hungary, Gulyas.Miklos@mkk.szie.hu (*corresponding author)Fuchs.Marta@mkk.szie.hu; \\ Fuleky.Gyorgy@mkk.szie.hu \\ ${ }^{2}$ Faculty of Economic, Agricultural and Healthcare Studies, Szent István University, \\ Szarvas, Hungary,Kocsis.Istvan@gk.szie.hu
}

Manuscript received 07. 08. 2014; revised 22. 08. 2014; accepted 10. 09. 2014

\begin{abstract}
The application of biochars to improve soils and to mitigate global climate change is a popular research area all over the world, although it is not a new topic. In our study, wood chips char (BC) and animal bone char $(\mathrm{ABC})$ were applied. The pot experiments were conducted under laboratory conditions. 2 grams of rye-grass (Lolium perenne) were seeded into each pot. The following various soil parameters were measured: $\mathrm{pH}(\mathrm{KCl}), \mathrm{AL}-\mathrm{P}_{2} \mathrm{O}_{5}, \mathrm{AL}-\mathrm{K}_{2} \mathrm{O}$, total water soluble salt content and organic matter content. The measured parameters from the plant samples were: total-P, total-K and micronutrients. Results show that the negative or positive effect of pyrolysis solids cannot be determined clearly, further experiments are needed.
\end{abstract}

Keywords: wood chips char, animal bone char, soil properties, nutrient uptake

\section{Introduction}

The application of different biochars to improve soils is a notable research area nowadays. Most of the biochar-application-related research has taken place in tropical environments [1]; so, the experiments on different climatic regions and different soil types are especially necessary.

Biochar as a material is defined as: "Biochar is a carbon-rich product of the pyrolysis process, intended to be used as a soil amendment to improve the physical and chemical characteristics of soils and to mitigate climate change by sequestering carbon. When applied to soil, biochar provides plant nutrients, increases surface 
area, CEC and water-holding capacity, and improves the soil as a microbial habitat" $[4,5]$.

The conditions of pyrolysis and feedstock types have a notable influence on the physical and chemical composition of the biochar. All these various properties determine its function, transport and fate in the environment, and, at last, the suitability for a given application. This heterogeneity renders the identification of the underlying mechanisms behind reported effects more difficult, but it also provides possibilities to engineer biochar with controlled properties [8].

The $\mathrm{pH}$ of biochars is usually neutral to basic; so, the biochar application has a liming effect on soils, which plays an important role in increasing plant productivity [8]. Biochar may also produce phytotoxic effects also due to the excessive soluble salts and the high $\mathrm{pH}$ [6]. Soluble salts are often present in the ash fraction of biochars, depending mostly on the mineral content of the feedstock [8].

Many studies have confirmed that biochar is a very efficient absorbent for nutrients $[2,3,5]$. The absorbance and slow release of plant nutrients of biochar provides a good feasibility to reduce the amount of fertilizers in agriculture.

Quilliama et al. found that biochar application benefits, e.g. improved soil nutrient levels or crop performance, seemed to be short-lived. The reapplication of biochar intensifies the short-term benefits rather than any lasting differences [7].

The goal of our experiment was to evaluate the effects of two types of pyrolysis solids as a potential soil amendment.

\section{Materials and methods}

The used soil samples were collected from the Ap horizon $(0-30 \mathrm{~cm})$ of an Arenosol from a research field plot of the Szent István University Crop Production and Biomass Utilization Centre, Gödöllö, Hungary. The air-dried samples were homogenized and were passed through a $2-\mathrm{mm}$ sieve to the analysis. The basic properties of the soil are given in Tab. 1.

Tab. 1. The basic physical and chemical properties of the soil used in the study

\begin{tabular}{|c|c|c|c|c|c|c|c|c|c|c|c|}
\hline $\begin{array}{l}\text { Genetic } \\
\text { horizon }\end{array}$ & Depth & OC & $\mathrm{CaCO}_{3}$ & pH & $\mathbf{p H}$ & CEC & $\begin{array}{c}\text { Total } \\
\text { salt }\end{array}$ & $\begin{array}{l}\mathrm{AL}- \\
\mathrm{P}_{2} \mathrm{O}_{5}\end{array}$ & $\begin{array}{l}\text { AL- } \\
\mathrm{K}_{2} \mathrm{O}\end{array}$ & hy & WHC \\
\hline & $(\mathrm{cm})$ & $\%$ & $\%$ & $\mathrm{H}_{2} \mathrm{O}$ & $\mathrm{KCl}$ & $\begin{array}{l}\mathrm{cmol} \\
\mathrm{kg}^{-1}\end{array}$ & $\%$ & $\begin{array}{l}\mathrm{mg} \\
\mathrm{kg}^{-1}\end{array}$ & $\mathrm{mg}_{1} \mathrm{~kg}^{-}$ & & $\%$ \\
\hline Ap & $0-30$ & 0.49 & - & 5.54 & 4.24 & 12.19 & 0.028 & 111.12 & 119.86 & 0.08 & 21.5 \\
\hline
\end{tabular}

Wood chips char (BC) and animal bone char (ABC) were produced in different Hungarian pyrolysis plants. Biochar properties are summarized in Tab. 2. 
Tab. 2. Characteristics of the two applied biochars

(BC: wood chips char, $\mathrm{ABC}$ : animal bone char)

\begin{tabular}{|c|c|c|}
\hline Parameters & BC & $\overline{A B C}$ \\
\hline Bulk density $\mathrm{g} \mathrm{cm}^{-3}$ & 0.36 & 0.31 \\
\hline Dry matter \% & 93.87 & 99.95 \\
\hline Ignition residue (ash) of dry matter \% & 11.61 & 100 \\
\hline Total carbon \% & 79.8 & 9.9 \\
\hline Total nitrogen $\%$ & 0.7 & 1.8 \\
\hline $\mathrm{C} / \mathrm{N}$ ratio $\%$ & 99.4 & 5.1 \\
\hline $\mathrm{pH}$ & 8.32 & 7.58 \\
\hline CEC cmol kg ${ }^{-1}$ & 14.7 & n.d. \\
\hline Calcium mg kg ${ }^{-1}$ & 30200 & 300000 \\
\hline Chromium $\mathrm{mg} \mathrm{kg}^{-1}$ & 4 & 4 \\
\hline Copper mg kg ${ }^{-1}$ & 9 & 5 \\
\hline Iron $\mathrm{mg} \mathrm{kg}^{-1}$ & 2280 & 63 \\
\hline Potassium $\mathrm{mg} \mathrm{kg}^{-1}$ & 4450 & 2000 \\
\hline Magnesium $\mathrm{mg} \mathrm{kg}^{-1}$ & 1200 & 6000 \\
\hline Manganese $\mathrm{mg} \mathrm{kg}^{-1}$ & 1140 & 1 \\
\hline Sodium $\mathrm{mg} \mathrm{kg}^{-1}$ & 170 & 7000 \\
\hline Phosphorus mg kg ${ }^{-1}$ & 780 & 133000 \\
\hline Zinc $\mathrm{mg} \mathrm{kg}^{-1}$ & 41 & 152 \\
\hline Sum of PAH mg kg & 4.82 & 0.37 \\
\hline Sum of PCB & - & - \\
\hline Nitrite $(\mathrm{KCl}) \mathrm{mg} \mathrm{kg}^{-1}$ & 0.4 & 0.6 \\
\hline Nitrate $(\mathrm{KCl}) \mathrm{mg} \mathrm{kg}^{-1}$ & $<10$ & $<10$ \\
\hline Potassium (AL) $\mathrm{mg} \mathrm{kg}^{-1}$ & 1450 & 1500 \\
\hline Phosphorus (AL) mg kg-1 & 214 & 24600 \\
\hline
\end{tabular}

In the pot experiment, two types of biochar were used. Predetermined amounts of biochars were added to the soil depending on the volume ratio contained (Tab. 3.). The four biochar application levels fitted to $1 \%(10 \mathrm{~g}), 2.5 \%$ $(25 \mathrm{~g}), 5 \%(50 \mathrm{~g})$ and $10 \%(100 \mathrm{~g})$. The $1,000-\mathrm{g}$ mixture was watered with $150 \mathrm{~cm}^{3}$ $\mathrm{kg}$ deionized water equivalent to $60 \%$ of the soil's plasticity. These mixtures were divided into four plastic containers; each container was filled with $200 \mathrm{~g}$ of biochar-amended soils. 2 grams of rye-grass (Lolium perenne) were seeded in each pot. The pots were later watered to weight. 
After the 4 weeks of the experiment, various soil parameters were measured: $\mathrm{pH}(\mathrm{KCl}), \mathrm{AL}-\mathrm{P}_{2} \mathrm{O}_{5}, \mathrm{AL}-\mathrm{K}_{2} \mathrm{O}$, total water soluble salt content and organic matter content according to Tyurin. The measured parameters for the plant samples were: total-P, total- $\mathrm{K}$ and micronutrients $(\mathrm{Ca}, \mathrm{Mg}, \mathrm{Cu}, \mathrm{Fe}, \mathrm{Mn}, \mathrm{Zn}, \mathrm{Cr})$.

Tab. 3. Parameters of treatments

\begin{tabular}{ccc}
\hline Treatments & Soil & Added pyrolysis solids \\
\hline BC10 & $990 \mathrm{~g}$ & $10 \mathrm{~g}$ wood chips char \\
BC25 & $975 \mathrm{~g}$ & $25 \mathrm{~g}$ wood chips char \\
BC50 & $950 \mathrm{~g}$ & $50 \mathrm{~g}$ wood chips char \\
BC100 & $900 \mathrm{~g}$ & $100 \mathrm{~g}$ wood chips char \\
ABC10 & $990 \mathrm{~g}$ & $10 \mathrm{~g}$ animal bone char \\
ABC25 & $975 \mathrm{~g}$ & $25 \mathrm{~g}$ animal bone char \\
ABC50 & $950 \mathrm{~g}$ & $50 \mathrm{~g}$ animal bone char \\
ABC100 & $900 \mathrm{~g}$ & $100 \mathrm{~g}$ animal bone char \\
Control $(\mathrm{C})$ & $1000 \mathrm{~g}$ & - \\
\hline
\end{tabular}

Differences in soil and plant properties between the treatments were statistically analysed using variance tests (Microsoft Excel. $\mathrm{P}<0.05$ ), while significant differences between individual treatments were determined by comparing the least significant difference (LSD) with the mean.

\section{Results and discussions}

The analysis of the soil after the reaping shows that both types of biochar (BC and $\mathrm{ABC}$ ) had an effect and even the two types have had some differences. The $\mathrm{pH}_{(\mathrm{KCl})}$ show that the treatments had an effect; the $\mathrm{pH}$ lift proportionately with the added products. This was expected from the related literature results, as biochar researches had shown a similar effect on soils as liming (Fig. 1).

As for the soluble salt concentration, it also got higher, especially in the case of the treatment noted as ABC (Fig. 2). The differences between the measurements are most possibly caused by the different raw material of the biochars. 


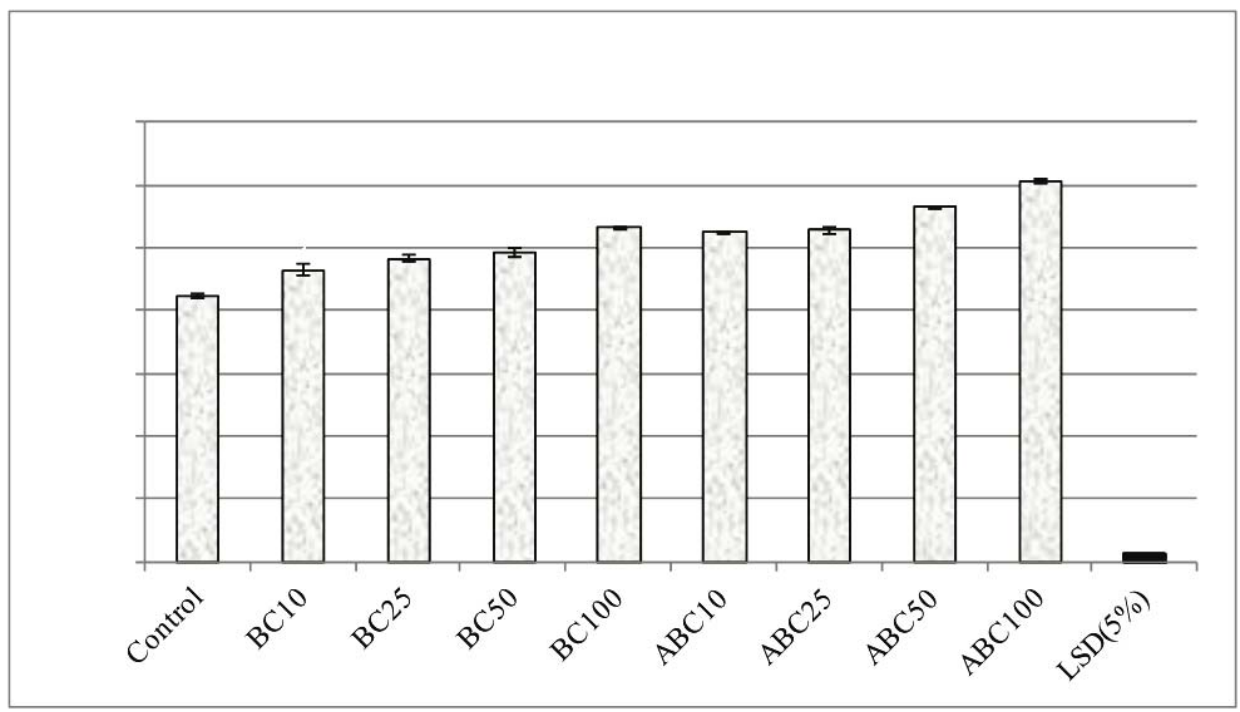

Fig. 1. Effect of different biochar treatments on the $\mathrm{pH}_{(\mathrm{KCL})}$ of soils

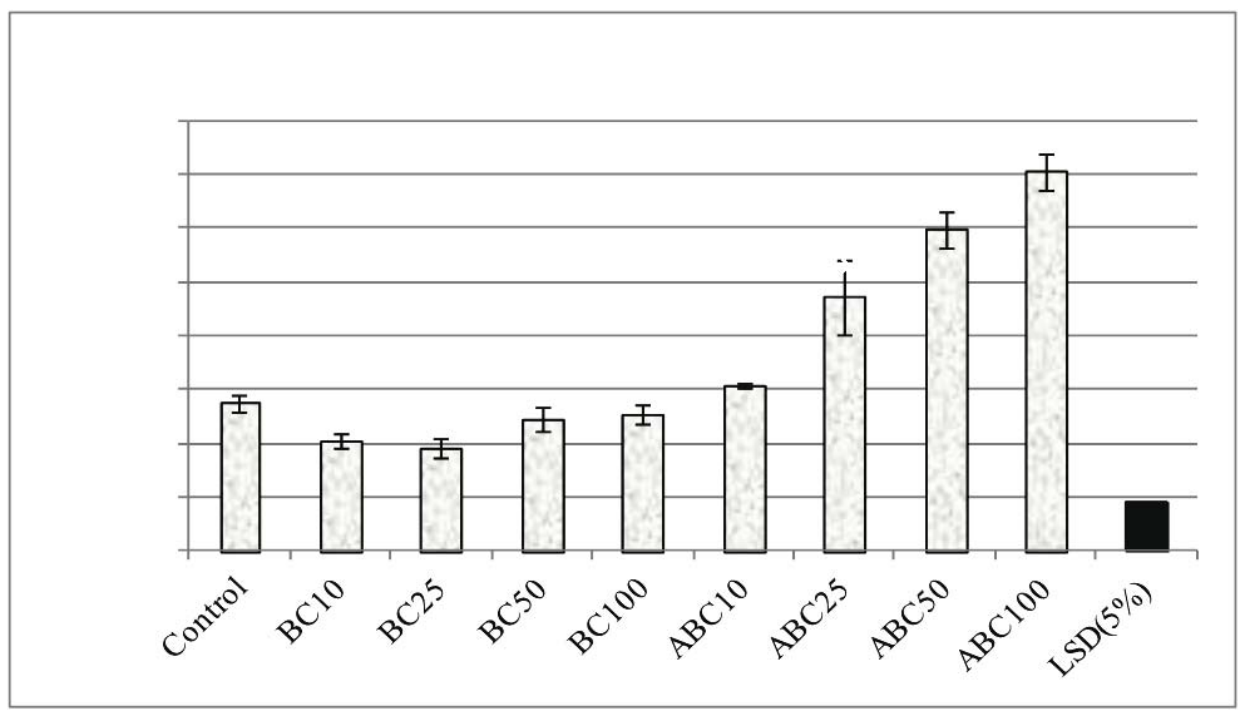

Fig. 2. Effect of different biochar treatments on the water soluble salt content of soils

As Fig. 3 shows, the bone char had great impact, proportionately with the added quantity. The differences between the measurements are expected and caused by the different raw materials of the biochars; the ones noted as $\mathrm{ABC}$ were 
made from animal bone, and so the material contained a much higher concentration of phosphorus.

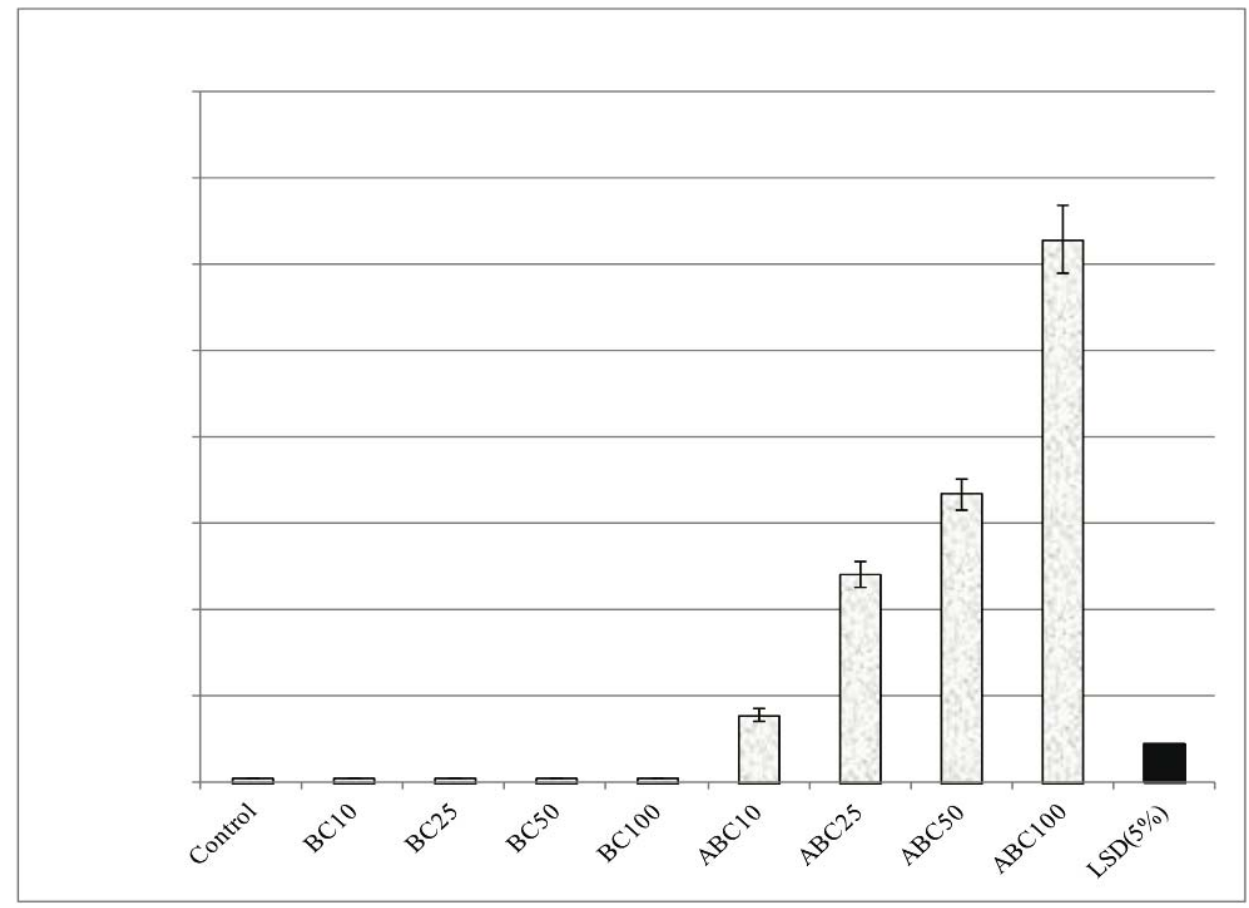

Fig. 3. Effect of different biochar treatments on the AL- $\mathrm{P}_{2} \mathrm{O}_{5}$ content of soils

The plant analysis shows that the biochar (wood chips char, animal bone char) application increased the air-dried mass of rye-grass in almost all cases, but this increase was not significant (Fig. 4). 


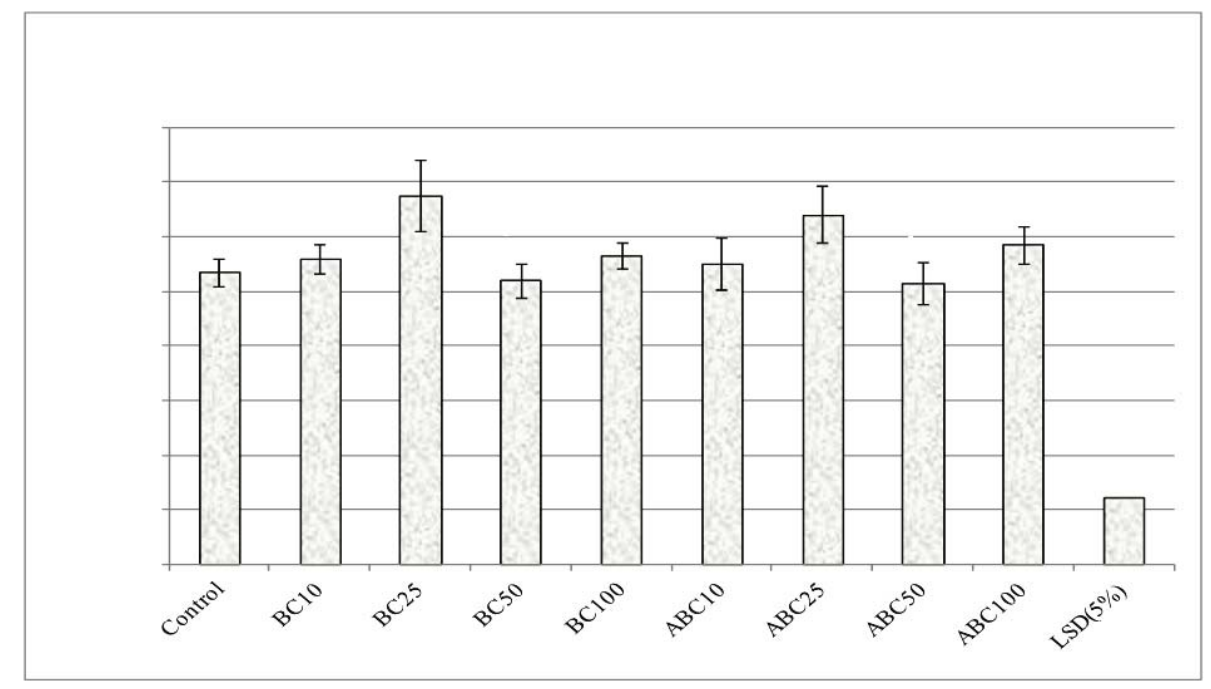

Fig. 4. Yield of test plants (Lolium perenne)

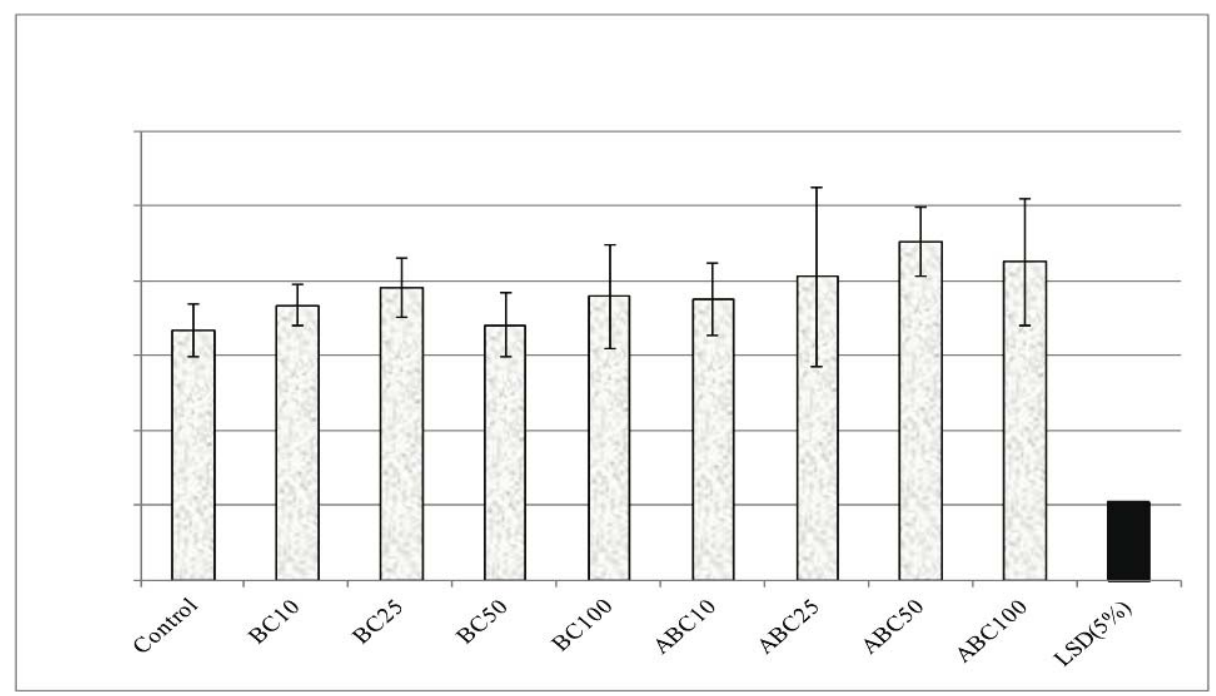

Fig. 5. Phosphorus uptake of test plants

Fig. 5 shows that the two types of biochar application increased the P-uptake (to one pot calculated); however, this increase did not show significant effect. The detected high $\mathrm{P}_{2} \mathrm{O}_{5}$ concentration in the soil due to the treatment, especially the bone char, had great amounts of phosphorus, but the test plants could not take up. 


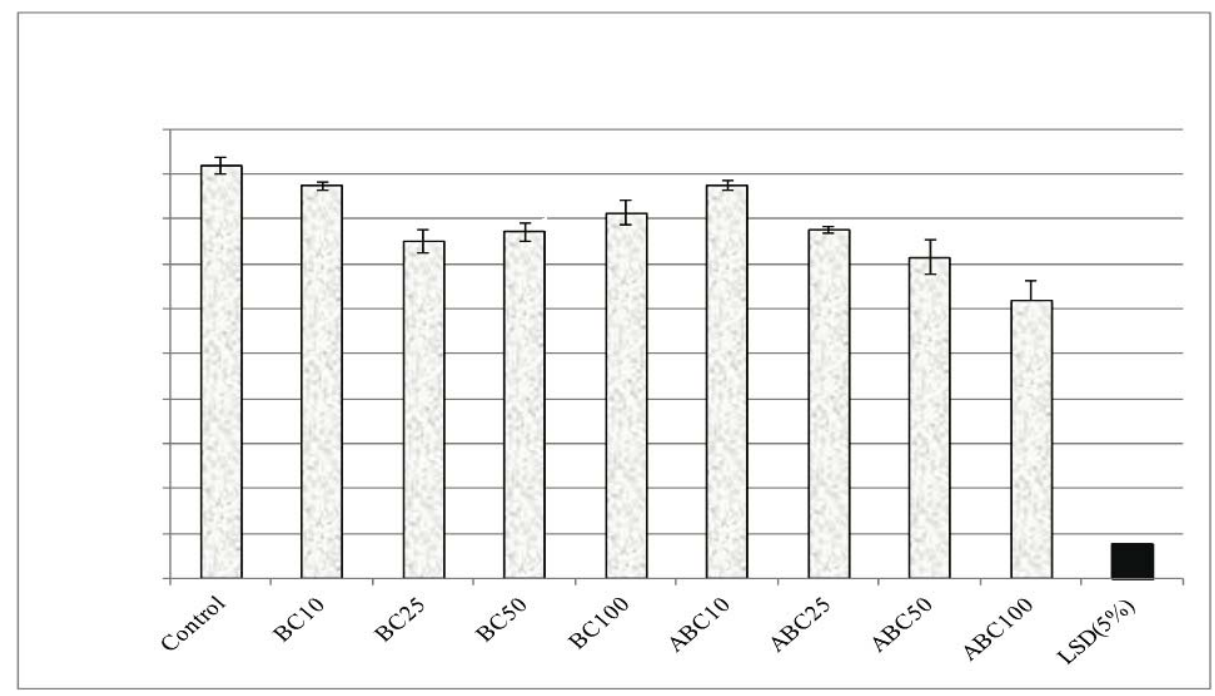

Fig. 6. Calcium concentration of test plants

The micronutrient analysis shows that the $\mathrm{Ca}$ concentration of test plants significantly decreased with the application rates of biochars (Fig. O). This effect is very similar to the phosphorous content of rye-grass. Although the wood chips char and animal bone char have outstanding calcium content, this high amount is mainly unusable for plants.

\section{Conclusion}

We found the applied animal bone char $(A B C)$ to be a good source of available phosphorous as it increased the easily soluble $\mathrm{P}_{2} \mathrm{O}_{5}$ content of the treated soil, but the plants could not take up such high amount in our short-term experiment.

The $\mathrm{pH}$ and water soluble salt content of the tread soil was increased significantly in the $\mathrm{ABC}$ treatments, while in the case of $\mathrm{BC}$ treatments the increase of $\mathrm{pH}$ was observed at all application rates and no effect on water soluble salt content was detected. The increase in $\mathrm{pH}$ and salt content did not cause very high alkalinity and/or salinity in neither treatment.

The application of pyrolysis products did not cause phytotoxic effects on test plants.

In our study, the high phosphorus content of $\mathrm{ABC}$ increased the easily soluble phosphorus content of soils. We suppose that the high Ca content of the applied biochars resulted in hardly soluble calcium phosphate forms and it prevented the uptake of the phosphate by the plants. 
Decreasing Ca uptake was observed on test plants, possibly due to the high carbonate content of the applied biochars, which may form insoluble calcium carbonates under alkaline $\mathrm{pH}$ conditions.

\section{Acknowledgements}

This research was supported by the Hungarian Government and the European Union, with the co-financing of the European Social Fund, within the framework of the TÁMOP-4.2.2.A-11/1/KONV-2012-0015 project and by the Hungarian Research Centre of Excellence - 7629-24/2013/TUDPOL fund.

\section{References}

[1] Glaser, B., Lehmann, J., Zech, W. (2002), Ameliorating physical and chemical properties of highly weathered soils in the tropics with charcoal - A review. Biology and Fertility of Soils $35,219-230$.

[2] Lehmann, J., da Silva Jr., J. P., Rondon, M., Cravo, M. S., Greenwood, J., Nehls, T., Steiner, C., Glaser, B. (2002), Slash-and-char - A feasible alternative for soil fertility management in the central Amazon? In: Proceedings of the $17^{\text {th }}$ World Congress of Soil Science, Symposium No. 13, 14-21 August 2002, Thailand.

[3] Lehmann, J., da Silva Jr., J. P., Steiner, C., Nehls, T., Zech, W. and Glaser, B. (2003), Nutrient availability and leaching in an archaeological Anthrosol and a Ferralsol of the Central Amazon basin: fertilizer, manure and charcoal amendments. Plant and Soil 249, 343-357.

[4] Lehmann, J., Gaunt, J., Rondon, M. (2006), Bio-char sequestration in terrestrial Ecosystems A review. Mitigation and Adaptation Strategies for Global Change 11, 403-427.

[5] Lehmann, J. (2007), Bio-energy in the black. Frontiers in Ecology and the Environment 5(7), 381-387.

[6] Smider, B., Singh, B., (2014), Agronomic performance of a high ash biochar in two contrasting soils. Agriculture, Ecosystems \& Environment 191, 99-107.

[7] Quilliama R. S., Marsdena K. A., Gertlerc, C., Rouska, J., DeLucaa, H. T., Jonesa, L. D. (2012), Nutrient dynamics, microbial growth and weed emergence in biochar amended soil are influenced by time since application and reapplication rate. A School of Environment, Natural Resources \& Geography, College of Natural Sciences, Bangor University, Bangor, Gwynedd, UK, Biological and Environmental Sciences, School of Natural Sciences, University of Stirling, Stirling, UK, School of Biological Sciences, College of Natural Sciences, Bangor University, Bangor, Microbial Ecology, Lund University, Ecology Building, Lund, Sweden.

[8] Verheijen, F., Jeffery, S., Bastos, A. C., van der Velde, M., Diafas, I. (2010), Biochar Application to Soils. A Critical Scientific Review of Effects on Soil Properties. Processes and Functions. EUR 24099 EN. Office for the Official Publications of the European Communities. Luxembourg. 